\title{
METODE MENULIS BERANTAI UNTUK MENINGKATKAN MOTIVASI DAN KETERAMPILAN MENULIS PANTUN SISWA
}

\author{
Sella Permata Sari, Sumarwati, Atikah Anindyarini \\ Universitas Sebelas Maret Surakarta \\ Email: permatasarisella@gmail.com,watik_uns@ymail.com, \\ atikahanindyarini@gmail.com
}

\begin{abstract}
Abstrak: Dalam menulis pantun ada aturan tertentu yang menjadi sumber kesulitan bagi siswa, seperti persajakan, jumlah suku kata, jumlah kata, jumlah kalimat, sehingga tidak semua siswa tertarik dan termotivasi melakukan tugas menulis pantun. Untuk itu, harus diupayakan pembelajaran berlangsung menyenangkan dan terjadi saling memotivasi juga saling melalui menulis berantai. Penelitian ini merupakan penelitian tindakan kelas untuk meningkatkan motivasi dan keterampilan menulis pantun siswa kelas VIIA SMP Negeri 1 Kebakkramat. Tindakan penelitian dilakukan dalam dua siklus. Teknik pengumpulan data yang diterapkan meliputi observasi, wawancara, dan analisis dokumen. Untuk menganalisis data digunakan teknik analisis statistik deskriptif komparatif dan analisis kritis. Hasil penelitian menunjukkan penerapan metode menulis berantai meningkatkan motivasi dan keterampilan menulis pantun. Peningkatan tersebut dapat dilakukan dengan prosedur pembelajaran berikut: (1) kelas dibagi menjadi 8 kelompok, masing-masing terdiri dari 4 siswa; (2) siswa bersama guru menentukan tema pantun; (3) siswa bersama anggota kelompoknya membuat kreangka pantun, (4) siswa pertama membuat satu baris pertama pantun; (5) siswa kedua membuat satu baris berikutnya dan baris selanjutnya dilanjutkan oleh siswa lain dalam kelompok hingga terbentuk pantun yang lengkap; (6) pada setiap akhir baris siswa menuliskan inisial nama untuk menandai nama penulis; (7) siswa bersama kelompoknya melakukan revisi; (8) pantun kemudian dibacakan anggota kelompok secara bergiliran; dan (9) guru dan kelompok lain menilai pantun yang dibacakan.
\end{abstract}

Kata kunci: menulis berantai, menulis pantun, motivasi menulis, aturan pantun

\section{WRITING SERIAL METHOD TO INCREASE STUDENTS'MOTIVATION AND SKILL OF PANTUN WRITING}

\begin{abstract}
In writing pantun 'Indonesian rhymes' there are certain rules which become a source of difficulty for students, such as taxation, syllable numbers, number of words, number of sentences, so that not all students are interested and motivated to do the pantun writing task. For this reason, learning should be fun and motivating each other through chain writing. This research is a classroom action research to improve motivation and writing skills of students in class VIIA SMP Negeri 1 Kebakkramat. The research action was carried out in two cycles. To analyze the data used comparative descriptive statistical analysis techniques and critical analysis. The results showed that the application of the chain writing method increased motivation and pantun writing skills. This improvement can be done with the following learning procedures: (1) the class is divided into 8 groups, each consisting of 4 students; (2) students and teachers determine the theme of pantun; (3) students and group members make pantun, (4) students make the first row of pantun; (5) the second student makes one next line and the next line is continued by other students in the group until a complete pantun is formed; (6) at the end of each line students write the initials to mark the name of the author; (7) students and their groups make revisions; (8) rhymes are then read in turn by group members; and (9) teachers and other groups assess the pantun read.
\end{abstract}

Keywords:estafet writing, pantun writing, the motivation of writing, pantun rules

BASASTRA Jurnal Bahasa, Sastra, dan Pengajarannya

Volume 8 Nomor 1, April 2020, P-ISSN 2302-6405, E-ISSN 2714-9765 


\section{PENDAHULUAN}

Menulis merupakan suatu keterampilan berbahasa yang digunakan untuk berkomunikasi secara tidak langsung. Menulis menurut Tarigan (2008: 3) yang berpendapat bahwa menulis merupakan suatu keterampilan berbahasa yang digunakan untuk berkomunikasi secara tidak langsung, tidak secara tatap muka dengan orang lain. Pendapat lain juga disampaikan oleh McCrimmon (dalam Saddhono dan Slamet, 2014: 150) yang menyatakan bahwa menulis merupakan kegiatan menggali pikiran dan perasaan mengenai suatu subjek, memilih hal-hal yang akan ditulis, serta menentukan cara menuliskannya sehingga pembaca dapat memahami dengan mudah dan jelas.

Senada dengan pendapat sebelumnya, Suparno dan Yunus (2014: 151) mendefinisikan menulis sebagai suatu kegiatan penyampaian pesan (komunikasi) dengan menggunakan bahasa tulis sebagai alat medianya. Pesan yang disampaikan tersebut tidak hanya berupa pikiran dan perasaan saja, melainkan juga berupa pengungkapan ide, pengetahuan atau ilmu, serta pengalaman hidup seseorang. Untuk itu, keterampilan menulis bukan hanya suatu kegiatan yang sederhana yang perlu untuk dipelajari, melainkan merupakan sebuah keterampilan yang penting untuk dikuasai.

Menulis termasuk dalam tataran keterampilan berbahasa yang sulit karena merupakan keterampilan yang dapat dipelajari setelah tiga keterampilan berbahasa yang lain sudah dikuasai. Sebagai suatu keterampilan, menulis dapat dikuasai melalui proses belajar dan berlatih. Keterampilan menulis sendiri sudah diajarkan di sekolah mulai dari jenjang taman kanak-kanak hingga jenjang sekolah menengah atas/kejuruan. Hal tersebut ditujukan agar siswa berlatih menuangkan ide, pikiran, gagasan, dan pendapatnya dalam bentuk tulisan dengan baik sejak dini. Akan tetapi pada kenyataannya, pelaksanaan pembelajaran menulis di sekolah masih mengalami berbagai macam kendala sehingga belum dapat terlaksana dengan baik.

Salah satu kompetensi dasar yang harus dikuasai siswa adalah keterampilan menulis pantun. Kompetensi dasar tersebut terdapat dalam silabus mata pelajaran Bahasa Indonesia SMP Kelas VII semester 2, Kompetensi Dasar (K.D.) 4.10 yaitu mengungkapkan gagasan, perasaan, pesan dalam bentuk puisi rakyat (pantun, syair, dan bentuk puisi rakyat setempat) secara lisan dan tulis dengan memperhatikan struktur, rima, dan penggunaan bahasa. Pantun menurut Suryaman dan Wiyatmi (2012: 77) merupakan puisi lama yang memiliki ciri bersajak a-b-a-b, tiap-tiap baitnya terdiri dari empat baris, yang mana dua baris awal merupakan sampiran dan dua baris akhir merupakan isi.

Menulis pantun bukan merupakan kegiatan yang mudah bagi siswa. Hal tersebut dapat ditemukan dalam penelitian Khoirotunnisa, Hasanah \& Dermawan (2018: 238) yang menemukan bahwa siswa mengalami kesulitan dalam menulis sampiran, menulis akhir bunyi, dan memilih tema pantun. Kesulitan yang sama juga dialami oleh siswa kelas VIIA SMP Negeri 1 Kebakkramat. Berdasarkan kompetensi dasar pelajarn bahasa Indonesia kelas VII, kondisi ideal siswa SMP kelas VII seharusnya sudah mampu menulis pantun dengan lancar. Akan tetapi pada kenyataannya, keadaan yang terjadi di lapangan menunjukkan bahwa masih banyak siswa yang kesulitan menulis pantun dengan baik. Berdasarkan hasil kegiatan pratindakan, keterampilan menulis pantun siswa kelas VIIA SMP Negeri 1 Kebakkramat tahun ajaran 2018/2019 dinilai masih rendah. Siswa yang telah mampu mencapai batas kriteria ketuntasan minimal (KKM $\geq 76)$ sebanyak $30 \%$ atau 9 siswa. Sedangkan siswa yang belum mencapai batas kriteriaketuntasan minimal $(K K M \geq 76)$ sebanyak $70 \%$ atau 21 siswa.

Wulandari, Fuady \& Sumarwati (2012: 79) mengungkapkan bahwa faktor utama penyebab siswa kesulitan dalam 
menulis salah satunya karena siswa tidak termotivasi. Padahal, motivasi menurut Wulandari, Fuady \& Sumarwati (2012: 79) merupakan suatu usaha yang disadari untuk menggerakkan, mengarahkan, dan menjaga tingkah laku seseorang agar dapat terdorong untuk bertindak melakukan sesuatu sehingga tujuannya tercapai. Kurangnya motivasi menyebabkan siswa sering kali kesulitan dalam menentukan dan mengembangkan sebuah topik, memilih kata atau kalimat yang tepat dan menarik, serta menggunakan ejaan dan tanda baca yang sesuai dengan pedoman.

Selain karena kurangnya motivasi, kendala pembelajaran menulis juga disebabkan oleh penggunaan metode pembelajaran yang kurang tepat. Wulandari, Fuady \& Sumarwati (2012: 80) mengungkapkan penggunaan metode pembelajaran yang kurang tepat dapat menyebabkan siswa merasa bosan dan tidak tertarik mengikuti pembelajaran menulis. Berdasarkan observasi awal, peneliti menemukan bahwa guru cenderung menggunakan metode pembelajaran konvensional. Pada proses pelaksanaannya, guru memberikan penjelasan dengan cara ceramah serta contoh yang singkat, kemudian langsung menugasi siswa untuk menulis. Hal ini mengakibatkan kreatifitas siswa tidak dapat berkembang dengan maksimal. Selain itu, siswa lebih tertarik dengan pembelajaran secar berkelompok dibanding dengan secara individu.

Kekurangan lain dari penerapan metode konvensional adalah tidak adanya feedback yang diberikan guru kepada siswa maupun siswa kepada siswa lain selama proses pembelajaran berlangsung. Pemberian feedback dalam pembelajaran menulis menurut Sharif dan Zainuddin (2017: 205) dapat meningkatkan rasa kebersamaan dan keterampilan sosial siswa, serta menciptakan sikap yang lebih positif dalam pembelajaran menulis. Selain itu pemberian feedback dari siswa kepada siswa lain (peer feedback) dapat membuka kesempatan bagi para siswa untuk memberi komentar, koreksi maupun saran terhadap hasil tulisan teman yang lain sehingga siswa dapat menjadi lebih aktif dalam mengikuti kegiatan pembelajaran (Spear; Williams dalam Noor, 2016: 12).

Berangkat dari permasalahan tersebut, dapat diketahui bahwa pemilihan dan penerapan metode pembelajaran memiliki peranan yang penting dalam proses berlangsungnya kegiatan pembelajaran. Pemilihan dan penerapan metode pembelajaran yang tepat dapat menjadi sarana untuk meningkatkan motivasi belajar dan keterampilan menulis siswa. Penerapan metode pembelajaran yang tepat juga dapat meminimalkan kemungkinan proses pembelajaran yang hanya didominasi oleh guru. Berdasarkan kondisi tersebut maka diajukan solusi penerapan metode pembelajaran menulis pantun secara berkelompok, yaitu metode menulis berantai.

Dengan demikian masalah penelitian ini dapat dirumuskan sebagai berikut: (1) apakah penerapan metode menulis berantai dapat meningkatkan motivasi menulis pantun? dan (2) apakah penerapan metode menulis berantai dapat meningkatkan keterampilan menulis pantun pada siswa kelas VIIA SMP Negeri 1 Kebakkramat tahun ajaran 2018/2019? Adapun yang menjadi tujuan pelaksanaan penelitian ini adalah meningkatkan (1) motivasi menulis pantun, dan (2) meningkatkan keterampilan menulis pantun pada siswa kelas VIIA SMP Negeri 1 Kebakkramat tahun ajaran 2018/2019 melalui penerapan metode menulis berantai.

Metode menulis berantai adalah salah satu metode active learning atau learning by doing yang bertujuan agar siswa mengasosiasikan belajar sebagai sebuahkegiatan yang menyenangkan (Syathariah, 2011: 41-42). Dalam proses pelaksanaannya, metode menulis berantai melibatkan siswa dalam proses belajar dengan carabersama-sama, tetapi tidak secara kelompok. Sehingga setiap siswa dapat berperan aktif menuangkan ide dan 
perasaan yang dimiliki dengan porsi yang sama.

Penerapan metode menulis berantai diharapkan mampu mengatasi permasalahan yang terdapat dalam proses pembelajaran menulis pantun di kelas VIIA SMP Negeri 1 Kebakkramat. Dengan diterapkannya metode ini, diharapkan mampu meningkatkan kualitas proses dan hasil pembelajaran menulis pantun. Penerapan metode ini juga diharapkan mampu menciptakan suasana belajar yang menyenangkan dan tidak membosankan karena siswa diberi kebebasan untuk mengekspresikan ide yang dimiliki.

Langkah-langkah pembelajaran menulis pantun dengan metode menulis berantai menurut Syatariah (2011) yaitu: (1) siswa dibentuk menjadi beberapa kelompok, setiap kelompok terdiri dari 4 siswa; (2) guru dan siswa menyepakati tema yang akan dibuat menjadi pantun; (3) selanjutnya, siswa pertama mulai menulis baris pertama pantun pada lembar kerja yang disediakan; (4) pada setiap akhir baris, siswa diminta untuk menuliskan namanya. Hal ini bertujuan untuk mengetahui pemilik baris yang tidak sesuai atau tidak koheren dengan baris sebelumnya; (5) setelah siswa pertama selesai menuliskan baris pertama, lembar kerja kemudian diserahkan pada siswa kedua; (6) siswa kedua membaca baris pertama pantun yang telah ditulis teman sebelumnya. Siswa kedua kemudian menuliskan baris kedua pantun pada lembar kerja, dan menuliskan namanya pada akhir baris; (7) lembar kerja kemudian diserahkan pada siswa ketiga untuk melakukan tugas yang sama, dan begitu seterusnya; (8) hasil pantun yang telah dikerjakan secara berantai tersebut kemudian dikoreksi secara bersama untuk mengetahui apakah ada kesalahan penulisan atau baris yang tidak sesuai; (9) setelah selesai, setiap anggota kelompok diminta untuk membacakan hasil pantun yang telah ditulis secara bergiliran, kemudian dinilai oleh guru dan kelompok lain.

\section{METODE PENELITIAN}

Penelitian ini dilakukan di SMP Negeri 1 Kebakkramat. Subjek penelitian ini adalah siswa kelas VIIA yang berjumlah 32 siswa yang terdiri dari 12 siswa laki-laki dan 20 siswa perempuan, serta guru pengampu mata pelajaran Bahasa Indonesia. Penelitian ini merupakan penelitian tindakan kelas yang dilaksanakan dengan adanya tahap persiapan dan pelaksanaan tindakan dalam dua siklus, yang mana setiap siklus mencakup 4 kegiatan, yaitu perencanaan, (2) pelaksanaan, observasi dan interpretasi, serta (4) analisis dan refleksi.

Rancangan tindakan pada siklus pertama adalah sebagai berikut. Tahap perencanaan meliputi kegiatan meyiapkan perangkat pembelajaran dan merancang skenario pembelajaran menulis pantun dengan penerapan metode menulis berantai. Tahap pelaksanaan dilakukan dengan mengadakan pembelajaran sebanyak 1 kali tatap muka pada tiap siklus dengan waktu 2x40 menit. Pada siklus I kegiatan pembelajaran dilakukan oleh guru, sedangkan peneliti melakukan observasi terhadap pelaksanaan proses pembelajaran. Tahap observasi dilaksanakan dengan mengamati proses aktivitas guru dan siswa selama proses pembelajaran. Selain itu, peneliti juga melakukan wawancara dengan siswa dan guru untuk memperoleh data yang lebih lengkap dan akurat. Tahap analisis dan refleksi dilakukan peneliti dan guru dengan menganalisis hasil pekerjaan siswa, hasil observasi, serta hasil wawancara.

Adapun rancangan pelaksanaan tindakan siklus II dilakukan dengan tahapan-tahapan seperti pada siklus I dengan perencanaan ulang berdasarkan hasil yang diperoleh dari tindakan siklus I. Perencanaan ulang tersebut untuk mengatasi kekurangan yang terjadi pada siklus I. 


\section{HASIL DAN PEMBAHASAN}

Penelitian diawali dengan kegiatan observasi pada survei awal untuk mengidentifikasi pelaksanaan proses pembelajaran menulis pantun yang dilakukan di kelas VIIA SMP Negeri 1 Kebakkramat. Kegiatan observasi ini bertujuan untuk mengetahui bagaimana kondisi awal siswa, sehingga peneliti dapat mengetahui tindakan seperti apa yang harus dilaksanakan ketika melaksanakan penelitian. Berdasarkan observasi ini diketahui bahwa siswa yang telah mencapai kriteria ketuntasan belajar (KKM $\geq 76$ ) sebanyak 9 siswa atau $30 \%$. Untuk lebih jelasnya dapat dilihat pada Tabel 1 berikut ini.

Tabel 1. Nilai Keterampilan Menulis Pantun pada Pratindakan

\begin{tabular}{ccccc}
\hline No & $\begin{array}{c}\text { Interval } \\
\text { Nilai }\end{array}$ & $\mathbf{f}$ & $\mathbf{\%}$ & Ket. \\
\hline 1 & $91-95$ & 1 & 3,33 & Kompeten \\
\hline 2 & $86-90$ & 0 & 0 & - \\
\hline 3 & $81-85$ & 0 & 0 & - \\
\hline 4 & $76-80$ & 8 & 26,67 & Kompeten \\
\hline 5 & $71-75$ & 11 & 36,67 & $\begin{array}{c}\text { Belum } \\
\text { Kompeten }\end{array}$ \\
\hline 6 & $66-70$ & 5 & 16,67 & $\begin{array}{c}\text { Belum } \\
\text { Kompeten }\end{array}$ \\
\hline 7 & $61-65$ & 0 & 0 & $\begin{array}{c}\text { Belum } \\
\text { Kompeten }\end{array}$ \\
\hline 8 & $56-60$ & 4 & 13,33 & $\begin{array}{c}\text { Belum } \\
\text { Kompeten }\end{array}$ \\
\hline 9 & $51-55$ & 1 & 3,33 & \\
\hline & Jumlah & $\mathbf{3 0}$ & $\mathbf{1 0 0 , 0}$ & \\
\hline
\end{tabular}

Nilai Rata-rata $=2164: 30=72,13$

Persentase Ketuntasan $=9: 30 \times 100 \%=$ $30 \%$

Berdasarkan tabel 1 dapat disimpulkan bahwa ada $70 \%$ siswa yang belum mencapai KKM atau belum kompeten.

\section{Tindakan Siklus I}

Setelah kegiatan obervasi dan survei awal dilaksanakan, langkah selanjutnya adalah penerapan tindakan pada siklus I. Siklus I diawali dengan penyamaan persepsi antara guru dan peneliti, menganalisis kelemahan-kelemahan pada kegiatan pratindakan, perumusan tujuan dan indikator pembelajaran, penyusunan RPP dan lembar observasi penelitian, serta penyusunan prosedur pembelajaran. Prosedur pembelajaran yang dilakukan pada kegiatan siklus I adalah sebagai berikut. Guru menetapkan tema untuk contoh pantun yang akan dibuat, yaitu bertema nasihat. Guru menuliskan 4 kata kunci yang akan digunakan sebagai patokan dalam membuat contoh pantun tersebut.

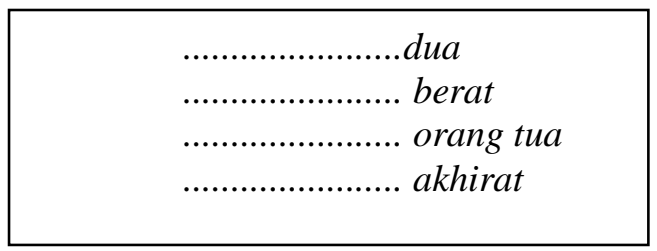

Selanjutnya, guru menuliskan baris pertama pantun tersebut yaitu,

\section{Buah nangka dibelah dua}

Pada langkah berikutnya, guru menawarkan kepada siswa untuk meneruskan baris pantun tersebut. Salah seorang siswa bernama CM mengacungkan jari, kemudian guru menyuruh $\mathrm{CM}$ untuk menyampaikan lanjutan baris pantun tersebut untuk kemudian dituliskan oleh guru di papan tulis. CM menulis sebagai berikut:

Yang satu ringan satunya berat

Guru kembali memberikan penawaran kepada siswa untuk meneruskan pantun tersebut. Seorang siswa bernama AMA mengacungkan jari dan kemudian menyampaikan baris lanjutan dari pantun tersebut.

Berbaktilah kepada orang tua

Sesudah itu, guru kembali menawarkan kepada siswa untuk melanjutkan baris terakhir pantun tersebut. Siswa bernama VM mengacungkan jari dan menyampaikan baris terakhir dari pantun tersebut. Verlinda menulis satu baris berbunyi: 
Agar selamat dunia akhirat

Selanjutnya guru dan siswa mengevaluasi hasil puisi yang telah dibuat. Di papan tulis tertulis satu bait pantun yang dibuat oleh guru dan siswa.

Buah nangka dibelah dua (Guru)

Yang satu ringan satunya berat (CM)

Berbaktilah kepada orang tua (AMA)

Agar selamat dunia akhirat (VM)

Siswa selanjutnya diminta untuk berkelompok dengan masing-masing kelompok terdiri dari 4 siswa. Setiap kelompok diberi tugas untuk membuat tiga bait pantun dengan tema yang sebelumnya telah ditentukan. Selanjutnya siswa membuat pantun yang ditulis secara bergiliran dengan anggota kelompok. Pada setiap akhir baris, siswa menuliskan namanya. Hal ini bertujuan untuk mengetahui pemilik baris yang tulisannya tidak sesuai. Hasil pantun yang ditulis secara berantai tersebut kemudian dibahas dengan kelompoknya. Setiap kelompok membacakan pantun yang telah dibuat secara bergiliran, sedangkan kelompok lain memberikan penilaian mengenai kekurangan dan kelebihan dari pantun tersebut.

Berdasarkan hasil observasi pada kegiatan siklus I diperoleh fakta: (1) peningkatan motivasi siswa yang meliputi: (a) perhatian siswa pada proses pembelajaran meningkat menjadi $82,1 \%$, (b) tingkat konsentrasi dan keaktifan siswa guru menyampaikan materi meningkat menjadi $82,1 \%$, (c) keaktifan siswa dalam kegiatan diskusi kelompok meningkat menjadi $78,6 \%$, serta (d) keaktifan siswa dalam kegiatan menulis pantun dengan metode menulis berantai meningkat menjadi $85,7 \%$; serta (2) sebanyak 24 siswa atau $85,71 \%$ siswa telah mencapai batas kriteria ketuntasan minimal (KKM) yaitu $\geq 76$, sedangkan 4 siswa yang lain atau $14,29 \%$ siswa belum mencapai batas KKM dan masih memerlukan perbaikan.
Berkaitan dengan hasil obervasi pada siklus I tersebut, kemudian dilakukan refleksi dengan hasil: (1) pada awal pembelajaran terdapat beberapa siswa yang masih sibuk dengan aktivitasnya sendiri karena siswa kurang tertarik dengan pembelajaran menulis pantun, sehingga mengakibatkan guru harus meluangkan waktu lebih untuk mengembalikan fokus siswa agar siap mengikuti pembelajaran. Hal ini akan diperbaiki dengan guru dapatbersikap lebih tegas pada siswa saat hendak memulai pembelajaran agar tidak menyia-nyiakan waktu, (2) guru tidak memberi perhatian penuh ketika siswa mengerjakan tugas sehingga kurang mendapat bimbingan dari guru. Hal ini akan diperbaiki dengan guru dapatberkeliling ke masing-masing kelompok saat siswa mengerjakan tugas yang diberikan, agar dapat memantau pekerjaan siswa secara lebih detail dan siswa merasa lebih diperhatikan.

\section{Tindakan Siklus II}

Tindakan dilanjutkan pada siklus II. Siklus II diawali dengan penyamaan persepsi antara guru dan peneliti, menganalisis kelemahan-kelemahan pada kegiatan pratindakan, perumusan tujuan dan indikator pembelajaran, penyusunan RPP dan lembar observasi penelitian, serta penyusunan prosedur pembelajaran. Prosedur pembelajaran yang dilaksanakan pada siklus II adalah sebagai berikut. Guru dan siswa terlebih dahulu membuat contoh pantun bertema pendidikan dengan menggunakan metode menulis berantai. Guru pada mulanya menuliskan 4 kata kunci, yaitu:

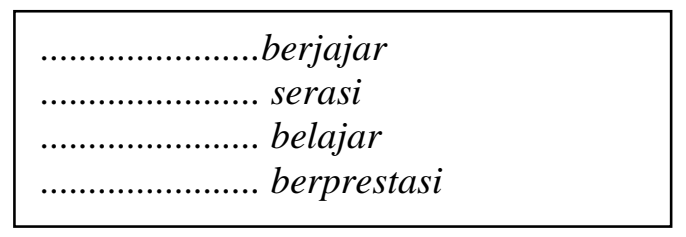

Guru kemudian mulai menuliskan baris pertama dari pantun tersebut yaitu: 
Siswa baris dengan bejajar

Selanjutnya, guru menawarkan kepada siswa untuk meneruskan baris pantun tersebut. Salah seorang siswa SF mengacungkan jari. Guru kemudian meminta SF untuk menyampaikan lanjutan baris pantun tersebut dan siswa menulis sebagai berikut.

\section{Dari depan tampak serasi}

Sesudah itu, guru kembali memberikan penawaran kepada siswa untuk meneruskan pantun tersebut. Seorang siswa bernama CS mengacungkan jari dan kemudian menyampaikan baris lanjutan dari pantun tersebut. CS menuliskan:

\section{Jadi murid harus rajin belajar}

Guru kemudian menawarkan kepada siswa untuk melanjutkan baris terakhirdan siswa bernama PNS mengacungkan, kemudian menuliskan baris terakhir.

Supaya pandai dan berprestasi

Dengan demikian, diperoleh satu bait pantun yaitu,

Siswa baris dengan berjajar (Guru)

Dari depan tampak serasi (SF)

Jadi murid harus rajin belajar (CS)

Supaya pandai dan berprestasi (PNS)

Siswa selanjutnya diminta untuk berkelompok dengan masing-masing kelompok terdiri dari 4 siswa. Setiap kelompok diberi tugas untuk membuat tiga bait pantun dengan tema yang sebelumnya telah ditentukan dengan didampingi guru. Selanjutnya siswa membuat pantun yang ditulis secara bergiliran dengan anggota kelompok. Pada setiap akhir baris, siswa menuliskan namanya. Hal ini bertujuan untuk mengetahui pemilik baris yang tulisannya tidak sesuai. Hasil pantun yang ditulis secara berantai tersebut kemudian dibahas dengan kelompoknya. Setiap kelompok membacakan pantun yang telah dibuat, sedangkan kelompok lain memberikan tanggapan mengenai kekurangan dan kelebihan dari pantun tersebut.

Berdasarkan hasil observasi pada kegiatan siklus II diperoleh fakta: (1) peningkatan motivasi siswa yang meliputi: (a) perhatian siswa pada proses pembelajaran meningkat menjadi $87,5 \%$, (b) tingkat konsentrasi dan keaktifan siswa guru menyampaikan materi meningkat menjadi 84,3\%, (c) keaktifan siswa dalam kegiatan diskusi kelompok meningkat menjadi $81,25 \%$, serta (d) keaktifan siswa dalam kegiatan menulis pantun dengan metode menulis berantai meningkat menjadi 87,5\%; serta (2) sebanyak 31 siswa atau $96,875 \%$ siswa telah mencapai batas kriteria ketuntasan minimal (KKM) yaitu $\geq 76$, sedangkan 1 siswa yang lain atau $3,125 \%$ siswa belum mencapai batas KKM dan masih memerlukan perbaikan.

Berkaitan dengan hasil obervasi pada siklus II tersebut, kemudian dilakukan refleksi dengan hasil: (1) meningkatnya jumlah siswa yang dapat mencapai batas kriteria ketuntasan minimal yang awalnya sebesar $85,71 \%$ pada siklus I menjadi $96,875 \%$ pada siklus II, (2) meningkatnya nilai rata-rata siswa yang semula 84,25 pada siklus I menjadi 87,34 pada siklus II, serta (3) meningkatnya motivasi belajar siswa dalam mengikuti pembelajaran menulis pantun.

Hasil pelaksanaan tindakan pada siklus I hingga siklus II di atas dapat dibuat rekapitulasi pada Tabel 2 
PTabel 2. Capaian Tindakan

\begin{tabular}{lccc}
\hline \multirow{2}{*}{ Indikator } & \multicolumn{3}{c}{ Persentase } \\
\cline { 2 - 4 } & $\begin{array}{c}\text { Pra- } \\
\text { tindakan }\end{array}$ & $\begin{array}{c}\text { Siklus } \\
\text { I }\end{array}$ & $\begin{array}{c}\text { Siklus } \\
\text { II }\end{array}$ \\
\hline $\begin{array}{l}\text { Perhatian } \\
\text { siswa pada } \\
\text { proses } \\
\text { pembelajaran. }\end{array}$ & $62,5 \%$ & $82,1 \%$ & $87,5 \%$ \\
$\begin{array}{l}\text { Keaktifan } \\
\text { siswa selama } \\
\text { penyemapian } \\
\text { materi }\end{array}$ & $62,5 \%$ & $82,1 \%$ & $84,3 \%$ \\
$\begin{array}{l}\text { Keaktifan } \\
\text { siswa dalam } \\
\text { kegiatan } \\
\text { diskusi. }\end{array}$ & $62,5 \%$ & $78,6 \%$ & $81,25 \%$ \\
$\begin{array}{l}\text { Keaktifan } \\
\text { siswa dalam } \\
\text { menulis } \\
\text { pantun. }\end{array}$ & $68,75 \%$ & $85,7 \%$ & $87,5 \%$ \\
\hline
\end{tabular}

Perbandingan persentase motivasi belajar yang dicapai pada pratindakan, siklus I, dan siklus II menunjukkan adanya peningkatan pada keempat indikator. Setiap indikator tersebut mengalami peningkatan yang cukup merata. Seperti pada indikator pertama yang mengalami peningkatan dari $62,5 \%$ pada pratindakan menjadi $82,1 \%$ pada siklus I, dan $87,5 \%$ pada siklus II. Pada indikator kedua peningkatan terjadi dari $62,5 \%$ pada pratindakan menjadi $82,1 \%$ pada siklus I, dan $84,3 \%$ pada siklus II. Peningkatan juga terjadi pada indikator ketiga yaitu $62,5 \%$ pada pratindakan menjadi $78,6 \%$ pada siklus I, dan $81,25 \%$ pada siklus II. Sedangkan indikator keempat yaitu $68,75 \%$ pada pratindakan menjadi $85,7 \%$ pada siklus I, dan $87,5 \%$ pada siklus II. Dengan demikian, secara keseluruhan terdapat peningkatan persentase pada semua indikator motivasi belajar dari satu siklus ke siklus berikutnya.
Tabel 3. Capaian Indikator Keterampilan Menulis Pantun

\begin{tabular}{lccc}
\hline Keterangan & $\begin{array}{c}\text { Pratin } \\
\text { dakan }\end{array}$ & Siklus I & $\begin{array}{c}\text { Siklus } \\
\text { II }\end{array}$ \\
\hline $\begin{array}{l}\text { Nilai rata-rata } \\
\text { Persentase } \\
\text { ketuntasan }\end{array}$ & 72,13 & 84,25 & 87,125 \\
& $30 \%$ & $85,71 \%$ & $\begin{array}{c}96,875 \\
\%\end{array}$ \\
\hline
\end{tabular}

Tabel 3 di atas menggambarkan adanya peningkatan pesat pada perolehan persentase ketuntasan keterampilan menulis pantun siswa kelas VIIA SMP Negeri 1 Kebakkramat yaitu $30 \%$ pada pratindakan menjadi $85,71 \%$ pada siklus I, dan $96,875 \%$ pada siklus II. Peningkatan juga terjadi pada peroleh nilai rata-rata menulis pantun yaitu 72,13 pada pratindakan menjadi 84,25 pada siklus I, dan 87,125 pada siklus II.

Hasil penelitian tindakan kelas ini menunjukkan secara keseluruhan ada peningkatan hasil pada semua indikator dari satu siklus ke siklus berikutnya. Adapun nilai positif hasil penelitian ini meliputi pembahasan sebagai berikut ini.

\section{Terjadinya koreksi antarsiswa dalam menulis berantai}

Metode menulis berantai dapat melatih siswa membuat pantun dengan lebih memperhatikan pemilihan kata, jumlah suku kata, serta persajakan yang sesuai dengan unsur-unsur pantun. Hal tersebut memungkinkan dilakukan siswa terhadap kinerjanya sendiri, maupun kinerja temannya. Dari hasil kerja bersama diidenfitikasi para siswa banyak melakukan koreksi baris pantun buatan temannya, kemudian siswa yang membuat baris tersebut melakukan koreksi. Pernyataan tersebut dapat dikaitkan dengan hasil penelitian Susanti (2014: 7) yang menemukan bahwa dengan menerapkan metode menulis berantai, siswa dapat menulis karangan narasi sesuai dengan karakteristik yang terdapat dalam karangan narasi. Begitu juga dalam penelitian ini, peneliti menemukan bahwa penerapan metode menulis berantai secara signifikan terbukti dapat mengurangi kesalahan atau 
ketidaksesuaian pada pemilihan kosakata, jumlah suku kata, serta persajakan pada proses menulis pantun yang terjadi pada masa pratindakan. Hal itu memungkinkan terjadi karena adanya saling mengoreksi pada siswa dalam satu kelompok. Menurut Sumarwati (2013) koreksi antar teman lebih efektif dibandingkan koreksi sendiri dalam kegiatan menulis karena sedseorang lebih menemukan kesalahan orang lain dan hal itu bisa menjadi refleksi bagi pengoreksi. Dengan demikian, pantun yang dihasilkan dengan menggunakan metode menulis berantai tersebut dapat memenuhi unsur-unsur pantun yang sesuai.

\section{Tumbuhnya kerja sama membangun imajinasi}

Metode menulis berantai dapat membantu siswa berlatih menulis pantun melalui penerapan metode yang tepat. Penerapan metode menulis berantai dalam pembelajaran menulis pantun terbukti dapat lebih memotivasi siswa dalam mengikuti proses pembelajaran sehingga siswa juga dapat meningkatkan hasil tulisannya. Dengan menulis secara bergilir, siswa mampu menulis baris-baris pantun yang kreatif dan imajinatif. Hal tersebut dapat dikaitkan dengan pendapat Syatariah (2011: 42) yang menyatakan bahwa metode menulis berantai merupakan metode inovatif yang membuat siswa aktif mengembangkan daya khayal dan imajinasinya. Metode menulis berantai dinilai mampu membangkitkan motivasi siswa dalam menemukan ide atau tema untuk dijadikan bahan dalam meghasilkan sebuah tulisan.

\section{Terjadinya proses menulis secara benar}

Penerapan metode menulis berantai dapat menciptakan proses menulis pantun yang berkualitas sehingga pantun yang dihasilkan juga berkualitas. Berdasarkan hasil penelitian yang diperoleh pada setiap siklus, dapat diketahui bahwa penerapan metode menulis berantai dapat meningkatkan motivasi serta keterampilan menulis pantun siswa kelas VIIA SMP
Negeri 1 Kebakkramat. Hal itu disebabkan siswa bersama temannya melalui kegiatan menulis dengan membuat rancangan terlebih dahulu, kemudian membuat draf, dan mengoreksi bersama. Hal itu dapat dikaitkan dengan simpulan Sumarwati (2019) bahwa dengan menulis berantai memungkinkan diterapkannya pendekatan menulis melalui proses kreatif yang benar, yaitu adanya tahap prapenulisan, tahap menulis, dan tahap pascamenulis. Pernyataan tersebut juga dapat dikaitkan dengan hasil penelitian Wulandari, Fuady, dan Sumarwati (2012: 89) yang menyimpulkan bahwa menulis puisi secara berkelompok dengan menerapkan metode menulis berantai akan menghasilkan puisi yang kualitasnya baik jika dimulai dengan penyusunan kerangka tulisan terelbih dahulu secara bersama-sama. Hal tersebut dipengaruhi oleh aktivitas-aktivitas dalam proses menulis puisi yang pada akhirnya juga berpengaruh terhadap tulisan yang dihasilkan.

\section{Tumbuhnya motivasi menulis}

Metode menulis berantai dapat membuat suasana belajar di kelas menjadi lebih menyenangkan. Syatariah (2011: 42) menyebutkan bahwa penerapan metode menulis berantai merupakan bentuk pengasosiasian belajar sebagai sebuah kegiatan yang menyenangkan. Setiap siswa diberi kebebasan untuk mengekspresikan imajinasinya dalam bentuk tulisan-tulisan imajinatif yang dihasilkan bersama teman-temannya. Pernyataan tersebut juga sejalan dengan penelitian Aswari (2014: 66) yang menemukan bahwa metode menulis berantai merupakan metode belajar menulis yang menyenangkan bagi siswa karena metode ini dapat meningkatkan minat siswa dalam mengikuti pembelajaran. Selain itu, Piga (2017: 43) dalam penelitiannya juga menyampaikan bahwa penerapan metode menulis berantai dalam pembelajaran menulis dapat membuat siswa menjadi lebih menikmati proses menulis. 
Pembelajaran menulis dengan menggunakan metode menulis berantai dapat membangkitkan motivasi siswa untuk menemukan ide untuk dijadikan sebagai bahan tulisannya. Peningkatan motivasi tersebut juga diiringi dengan peningkatkan fokus dan konsentrasi siswa selama mengikuti kegiatan pembelajaran menulis di kelas. Hal tersebut dapat dikaitkan dengan penelitian Puspita (2016: 162) bahwa penerapan metode menulis berantai membuat siswa lebih semangat, antusias, dan bersungguh-sungguh dalam mengikuti kegiatan pembelajaran.

\section{Meningkatnya interaksi antarsiswa}

Metode menulis berantai merupakan metode pembelajaran interaktif yang dapat menstimulasi motivasi siswa dalam proses pembelajaran. Penerapan metode menulis berantai dapat merangsang siswa dalam proses pembelajaran, sehingga siswa mampu memperoleh hasil belajar yang lebih baik. Pernyataan tersebut dapat dikaitkan dengan pendapat Bolkan, Goodboy, dan Griffin (2011: 344) dalam penelitiannya yang menyimpulkan bahwa ketika guru menerapkan metode pembelajaran interaktif yang menstimulasi

\section{REFERENSI}

Aswari, D.W. (2014). Penggunaan Metode Menulis Berantai dan Media Lagu untuk Meningkatkan Minat serta Kemampuan Menulis Puisi pada Siswa Kelas VIIIC SMP Negeri 2 Weru. Skripsi. Universitas Sebelas Maret, Surakarta.

Atori, A. M., Sunarya, D.T., \& Gusrayani, D. (2016). Penerapan Permainan Estafet Word Writing untuk Meningkatkan Hasil Belajar Siswa dalam Materi Keterampilan Menulis Puisi Bebas. Jurnal Pena Ilmiah, 1 (1), 711-720.

Bolkan, S., Goodboy, A.K., \& Griffin, D.J. (2011). Teacher Leadership and Intellectual Stimulation: Improving Students' Approaches to Studying siswa, siswa akan dapat belajar dengan lebih mendalam dan dengan cara yang strategis. Sehingga, pada akhir pembelajaran dapat diperoleh hasil belajar yang positif.

\section{SIMPULAN}

Simpulan yang dapat diperoleh dari penelitian ini adalah penerapan metode menulis berantai dapat meningkatkan motivasi belajar menulis pantun siswa kelas VIIA SMP Negeri 1 Kebakkramat. Hal tersebut dapat tampak pada peningkatan persentase indikator-indikator yang mengukur motivasi belajar siswa. Indikator-indikator tersebut antara lain: (1) keaktifan dan antusiasme siswa dalam megikuti proses pembelajaran mengalami peningkatan (2) tingkat konsentrasi dan keaktifan siswa guru menyampaikan materi, (3) keaktifan siswa dalam kegiatan diskusi kelompok; (4) keaktifan siswa dalam kegiatan menulis pantun. Penerapan metode menulis berantai dinilai juga dapat meningkatkan keterampilan menulis pantun siswa. Peningkatan tersebut dapat terlihat pada perolehan persentase ketuntasan keterampilan menulis pantun siswa.

through Intrinsic Motivation. Communication Research Reports, 28 (4), 337-346.

Citraningrum, D.M. (2016). Menulis Puisi dengan Teknik Pembelajaran yang Kreatif. Jurnal Belajar Bahasa, 1 (1), 82-90.

Despita, R., \& Montesori, M. (2015). Peningkatan Motivasi Belajar Siswa Melalui Project "Globalisasi" dalam Pembelajaran IPS. Jurnal EDUCATO, 5 (1), 1-6.

Harijatiwidjaja, N. (2016). Peningkatan Kemampuan Menulis Eksposisi Melalui Model Menulis Cerita Berantai. Jurnal Metalingua, 14 (1), 103-116. 
Hulpa, W. N., Djuanda, D., \& Hanifah, N. (2016). Penerapan Metode ESCO (Estafet Writing and Collaborative Writing) dengan Media Gambar untuk Meningkatkan Kemampuan Melengkapi Cerita Rumpang. Jurnal Pena Ilmiah, 1 (1), 741-750.

Hyland, K. (2008). Writing Theories and Writing Pedagogies. Indonesian Journal of English Language Teaching, 4 (2), 1-20.

Iftanti, E. (2016). Improving Students' Writing Skills through Writing Journal Articels. Lingua Scienta, 8 (1), 1-22.

Khoirotunnisa, R.P., Hasanah, M., \& Dermawan, T. (2018). Pengembangan Bahan Ajar Menulis Pantun Bermuatan Nilai Budaya dengan Strategi Pohon Kata untuk Siswa Kelas VII. Jurnal Pendidikan: Teori, Penelitian, dan Pengembangan, 3 (2), 238-344.

Kusmana, S. (2014). Kreativitas Menulis. Yogyakarta: Penerbit Ombak.

Multafifin. (2015). Kemampuan Menulis Pantun Siswa Kelas VII SMP Negeri 52 Konawe Selatan. Jurnal Humanika, 2 (15), 1-12.

Noor, M. (2016). Improving the Ability in Writing Narrative Text of Junior High School Students through Peer Feedback. Indonesian Journal of English Language Teaching and Applied Linguistics, 1 (1), 11-21.

Piga, G.H. (2017). Improving the Eleventh Grade Students of SMA N 1 Raijua in Writing Narrative Text through Estafet Writing Teaching Model in Academic Year 2016/2017. International Journal of English and Education, 6 (4), 34-45.

Puspita, H. (2016). Peningkatan Kemampuan Menulis Paragraf Deskriptif Siswa Kelas X SMA Negeri 02 Bengkulu Tengah dengan Menggunakan Metode Menulis Berantai (Estafet Writing). Jurnal Pendidikan Bahasa dan Sastra Indonesia, 2 (2), 157-163.
Rahmawati, N. (2017). Peningkatan Kemampuan Menulis Puisi Bebas Melalui Penggunaan Metode Estafet Writing (Penelitian Tindakan Kelas pada Siswa Kelas VIIIF SMP Negeri 1 Baregbeg). Jurnal Diksatrasia, 1 (2), 115-123.

Sardiman, A.M. (2012). Interaksi dan Motivasi Belajar Mengajar. Jakarta: Rajawali Press.

Semi, M.A. (1995). Metode Penelitian Sastra. Bandung: Angkasa.

Setiawan, G.K. (2018). Peningkatan Kemampuan Menulis Pantun dengan Menggunakan Metode Menulis Berantai Studi Eksperimen pada Siswa Kelas VII SMPN 1 Kadungora Kabupaten Garut Tahun Pelajaran 2016/2017. Caraka: Jurnal Pendidikan Bahasa dan Sastra Indonesia serta Bahasa Daerah, 7 (1), 38-51.

Sharif, A.M. \& Zainuddin, S.T. (2017). Students' Perceptions of Their Reflective Essay Writing Experience and Teacher Feedback Comment. Indonesian Journal of Applied Linguistics, 6 (2), 204-212).

Soetarno. (2008). Peristiwa Sastra Melayu Lama. Surakarta: PT Widya Duta Grafika.

Sumarwati. (2019). Peningkatan Kualitas Pembelajaran Menulis melalui Pendekatan Proses pada Siswa di Kelas V Sekolah Dasar, Jurnal Logat, 6(2), 151-167.

Somekh, B. \& Zeichner, K. (2008). Action Research for Educational Reform: Remodelling Action Research Theories and Practices in Local Context. Educational Action Research, 17 (1), 5-21.

Sugiyarto, E. (2012). Pantun dan Puisi Lama Melayu. Yogyakarta: Kithah Publishing.

Sumarwati. (2013). Teknik Peer-correction dalam Pembelajaran Menulis untuk Meningkatkan Penguasaan Kaidah 
Bahasa Indonesia Siswa Sekolah Menengah, Pedagogia, 16(1), 1-12.

Suparno \& Yunus, M. (2008). Keterampilan Dasar Menulis. Jakarta: Universitas Terbuka.

Suprihatin, S. (2015). Upaya Guru dalam Meningkatkan Motivasi Belajar Siswa. Jurnal Pendidikan Ekonomi UM Metro, 3 (1), 73-82.

Suryaman, M., \& Wiyatmi. (2012). Puisi Indonesia. Yogyakarta: Penerbit Ombak.

Susanti, A. (2014). Peningkatan Keterampilan Menulis Karangan Narasi melalui Penggunaan Strategi Estafet Writing pada Mata Pelajaran Bahasa Indonesia Siswa Kelas V SDIT Luqman Al Hakim Kecamatan Sukodono Kabupaten Sragen Tahun Ajaran 2013/2014. Naskah Publikasi. Universitas Muhammadiyah Surakarta, Surakarta.

Syathariah, S. (2011). Estafet Writing (Menulis Berantai). Yogyakarta: Leutika Prio.

Tarigan, H.G. (2008). Menulis sebagai Suatu Keterampilan Berbahasa. Bandung: Angkasa.

Vinorita, D., \& Muhsin. (2018). Pengaruh Perhatian Orang Tua, Komunikasi Guru, Pemberian Reward, dan Fasilitas Belajar terhadap Motivasi Belajar. Economic Education Analysis Journal, 7 (2), 553-567.

Widya, W. (2008). Bedah Puisi Lama. Klaten: Intan Pariwara.

Wulandari, T., Fuady, A. \& Sumarwati. (2012). Peningkatan Motivasi dan Kemampuan Menulis Puisi melalui Penerapan Metode Menulis Berantai pada Siswa Sekolah Menengah Atas. Jurnal Penelitian Bahasa, Sastra Indonesia dan Pengajarannya, 1 (1), 77-92. 